\title{
Corporate Governance, Globalisation and Firm Productivity
}

Byung Min and Russell Smyth

Published in Journal of World Business

\begin{abstract}
We examine the relationship between globalisation, corporate governance and firm productivity. The results, using longitudinal data from Korea, indicate that the positive effect of liberalising equity ownership on firms' total factor productivity (TFP) was reinforced by indirect managerial effects when a firm improved its corporate governance. Our findings also confirm that the interaction of the managerial effect with increased foreign equity ownership is more significant than interaction with exports, suggesting that liberalising foreign investment in the host market is more effective in capitalising on the potential benefits of corporate governance reform than increasing exports to overseas markets, reflected in learning by exporting.
\end{abstract}

Key words: corporate governance reform; globalisation; productivity; Korea 


\section{Introduction}

Asian corporations have come to play a significant role in the global market (Peng, Bhagat \& Chang, 2009), but have proved vulnerable to financial shocks (Forbes, 2004). Recurrent financial crises have highlighted the importance of corporate governance and managerial effort in improving firm productivity in a rapidly globalising Asia. The purpose of this paper is to examine the association between corporate governance, globalisation and a firm's total factor productivity (TFP) by disentangling total effects into direct and indirect effects. To realize our purpose, we use longitudinal data for Korea, where firms' level of globalisation, measured by foreign equity ownership and exports, and corporate governance systems have changed significantly since the 1990s. Most existing corporate governance studies examine the relationship between corporate governance and share price or accounting performance. ${ }^{1}$ In contrast to the existing literature on accounting profits and/or share price effects of corporate governance, we examine the real consequences of changes in corporate governance, measured in terms of effects on a firm's TFP.

There is a large literature on the factors that drive TFP improvement at the firm level. Syverson (2011), who presents a comprehensive survey, states that the extant literature has suggested that there are several internal and external drivers of differences in firm level TFP. The internal drivers are managerial talent, the quality of general capital and labor inputs, research and development and information technology, learning by doing, firm structure decisions and product innovation. The

\footnotetext{
${ }^{1}$ Most of the existing literature suggests a positive association between corporate governance and accounting performance (see Morck, Wolfenzen \& Yeung, 2005; Perez-Gonzalez, 2006 for surveys). Studies of Korean firms based on this approach have produced similar results. Joh (2003) explored changes in accounting profits associated with corporate governance failure in Korean firms before the 1997 financial crisis. Black, Jang and Kim (2006) reported that the share price of a firm increased sharply with the appointment of outside directors to more than 50 per cent of positions on the board. Park and Kim (2008) reported that the effectiveness of appointment of outside directors on firms' financial performance is bound to the institutional context created by government regulation.
} 
external drivers are productivity spillovers, intra-market competition, industry deregulation, flexibility of input markets and trade competition. Hayakawa et al (2012) present a review of the large number of studies which have just considered the relationship between globalisation and firm level TFP. Their survey defines globalisation in terms of the firm's exports and imports, firm's outward investment, foreign investment in the firm and trade liberalization/import competition in the industry in which the firm operates. Their review of the literature suggests that engaging in trade (exporting and/or importing), outward investment and inward investment into the firm contributes positively to firm TFP. Trade liberalization has asymmetric effects on TFP; trade liberalization at home reduces firm survival at home, forcing out low productivity firms, while trade liberalization in foreign countries decreases the productivity threshold for exporting and raises survival rates. Another measure of globalisation that has been used in the context of firm-level TFP studies is outsourcing. For example, Girma and Gorg (2004) found that outsourcing to foreign firms had a positive effect on TFP in UK manufacturing firms.

Compared with the vast international evidence on the determinants of firmlevel TFP, the evidence for Korea is relatively scant. Oh (2011) examined the determinants of firm-level TFP in Korean manufacturing over the period 1993 to 2003. His results suggest that market competition, research and development (R\&D) activities, export activities and product innovation were the main drivers of TFP. Heshmati and Kim (2011) found that investment in R\&D had a positive effect on TFP in Korean firms over the period 1986 to 2002. Kim (2013) found that corporate taxes had a negative effect on Korean firm productivity over the period 1980 to 2010 . Other studies compare firm level TFP and its determinants in Korea with its Asian neighbors (Fukao et al., 2011; Kim \& Ito, 2013). Fukao et al. (2011) found that TFP 
levels in Chinese and Korean manufacturing firms were lower than in Japanese manufacturing firms, but Korean firms were catching up to their Japanese counterparts. By contrast, Kim and Ito (2013) found that average TFP in Korean firms was not catching up to Japanese firms. Their explanation for this finding is that while the rate of return on $\mathrm{R} \& \mathrm{D}$ activities is higher for large/productive Korean firms than Japanese firms, the rate of return on research activities for smaller/less productive firms is the same in the two countries.

We extend the existing literature on the determinants of firm-level TFP in that our focus is on the association between globalisation and productivity together with corporate governance in order to analyse indirect managerial effects. This approach enables us to investigate the channel through which globalisation affects productivity and, in particular, allows us to examine the importance of managerial effort as a determinant of different input combinations and in shifting the production function. Our focus on Korean firms to study this relationship is important in view of the studies by Doidge, Karolyi, and Stulz (2007) and Aguilera and Jackson (2003), which demonstrated that country-specific factors are important in understanding corporate governance. Korean listed industrial firms have experienced dramatic change in both their degree of globalisation and corporate governance system, which presents a different, and very relevant, context from that of stable advanced economies.

Our estimation uses firm-based data, rather than country-level aggregated data, which allows us to estimate firm productivity using Olley and Pakes' (1996) estimation methods in order to minimise possible simultaneity biases (Levinsohn and Petrin, 2003). The appointment of outside directors in Korea is somewhat arbitrary. The amended Listing Act requires that in all listed firms outside directors should represent at least 25 per cent of its board members. However, actual appointments 
differ; some did not meet this 25 per cent requirement and some did not appoint outside directors at all. This may cause an endogeneity problem. We employ the GMM method of instrument variable estimation to address the possible endogeneity problem associated with the appointment of outside directors in robustness checks

We follow Sutcliffe and Glyn (2003), in their entry on measures of globalisation in the Handbook of Globalisation, and define globalisation as the increasing international integration of economic activity. As discussed above, in firm level studies of TFP, globalisation has been measured in at least six ways (firm's exports, firm's imports, firm's outward investment, foreign investor's equity ownership in the firm, firm's outsourcing overseas and import penetration/trade liberalization). Trade liberalization is sometimes divided into subcategories, such as import penetration from low-wage countries and imports from other countries in the industry in which the firm is located (see eg. Kneller et al., 2012).

We focus on foreign ownership and exports as our measures of globalisation. We do so because our dataset does not have measures on the other measures of globalisation that have been used in various firm-level TFP studies. We believe, none the less, that these measures are useful proxies for globalisation in the Korean context. This reflects the fact that both foreign equity ownership and exports are generally recognized as having had the most important roles in terms of globalisation of the Korean economy (Turner \& Kim, 2004; Page, 1994; Pack \& Page, 1994).

Korea is regarded as one of the most successful examples of export-led industrialization. Exports as a percentage of GDP increased from 3.2 per cent in 1960 to 56.2 per cent in 2011 (World Bank, 2013). Foreign direct investment was minimal from the 1960 s to mid-1980s, but started to increase with liberalization of investment policies in the 1990s. Since the onset of the financial crisis in 1997, the Korean 
government has been active in its efforts to attract foreign direct investment to Korea; passage of the Foreign Investment Promotion Act in 1998 greatly facilitated these efforts. The Act opened up 99.8 per cent of Korea's industries to foreign investment and provided significant protection for investors' interests. Under the Act, foreign investors also receive incentives including tax breaks and cash grants. Thus, foreign direct investment in Korea increased from \$US100 million at the beginning of the 1980s to \$US 3 billion in 1997 to \$US16.3 billion in 2012 (MOTIE, 2013).

While these figures remain modest relative to some of Korea's neighbors, such as China, foreign direct investment has played an important role in facilitating Korea's industrialization, it has substantially contributed to the success of its exportled strategy and been important in upgrading local technological capabilities. Industries, such as heavy machinery, petrochemicals and petrol refining would never have been established in the absence of foreign direct investment. Foreign direct investment was instrumental in establishing fast-growing export lines, such as electronics (Nicholas, 2003; Turner \& Kim, 2004). In this sense, it is a good indicator, along with exports, of how globalisation has restructured the Korean economy.

Corporate governance is a general term referring to institutions designed to monitor the actions of management with a view to mitigating the adverse effects of agency risk. In this paper, we focus on one particular aspect of corporate governance, which is the appointment of outside directors and the ratio of outside directors to board members. Our primary reason for relying on this particular proxy is, as with our proxies for globalisation, access to data. We use firm level data to analyze the relationship between corporate governance, globalisation and TFP and the proportion of outside directors is the only characteristic of corporate governance that is available 
in such datasets for Korea. There is no publicly available data, at least at the firm level, which captures the multiple elements of corporate governance in Korea.

While the decision to use outside directors as our measure of corporate governance is dictated by data availability, we still believe that it is a very good proxy for corporate governance in the Korean context. First, as outlined in more detail in the next section, the proportion of outside directors in Korean companies has been the most important feature of corporate governance in Korea. Given this importance, it is the component of corporate governance in Korea that has attracted the most attention. Second, in focusing on the proportion of outside directors as our measure of corporate governance, we follow the extant literature which has examined the relationship between corporate governance and firm activity in Korea (Choi et al. 2007; Black et al. 2006; Kim \& Lim, 2010; Chizema \& Kim 2010; Min \& Verhoeven, 2013).

Foreshadowing our main results, we find that the effects of globalisation on firm productivity are larger in firms with more outside directors and that this relationship is stronger when globalisation is measured in terms of foreign equity ownership than exports. This result suggests that liberalising foreign investment in the host market is more effective in capitalising on the potential benefits of corporate governance reform than increasing exports to overseas markets

The layout of this paper is as follows. The next section describes the Korean context. In Section 3 we outline existing theories on the relationship between corporate governance, globalisation and firm productivity. This section presents our analytical framework, testable hypotheses and empirical specification used to test those hypotheses. In section 4 we describe the data. The results are presented in Section 5. A discussion of the managerial implications of the main findings is presented in Section 6. The final section concludes with a summary of the results. 


\section{The Korean Context}

It is well known that the achievements of the Korean economy are largely due to its outward development strategies since the 1960s (see Amsden, 1989; Page, 1994; Turner \& Kim, 2004 among others). To secure foreign currency, exports were encouraged through various monetary and fiscal subsidies. In particular, the focus on heavy and chemical industries (HCI) strategically pursued in the 1970s reinforced the position of the existing business groups and promoted the formation of a number of new business groups. The government protected entrepreneurs' ownership and managerial control by limiting foreign ownership to 10 percent and prohibiting (hostile) mergers and acquisitions (M\&As) based on an expectation that these groups would foster HCI.

The Korean government began to open equity markets to foreign investors in 1992 when the economy required foreign capital because of accumulated current account deficits. However, the extent of foreign equity ownership was limited due to the restriction that foreigners not hold more than 50 percent of the issued shares in Korean companies. The 1997 financial crisis, and the subsequent reforms, were a turning point that led to the relaxation of most restrictions on foreign ownership. The regulations governing foreign investors' ownership of Korean firms were almost completely removed. Foreign equity investment has been liberalized, such that since May 1998 there are no restrictions, except for those industries involving national security concerns or cultural sensitivities, such as the mass media.

While Korean development was based on export-driven growth from the 1960s and equity markets have been liberalised since the early 1990s, most Korean 
firms had weak corporate governance systems until the onset of the 1997 financial crisis. Virtually all of the (unitary) boards of directors (BOD) of Korean firms were appointed internally, and the controlling shareholder of the chaebol, as a non registered board member, held a significant amount of economic (and political) power (Kim \& Kim, 2008). This power was backed up by his/her tenured position, which resulted from the complicated ownership arrangements between chaebol affiliates. Consequently, internally appointed board members tended to act as rubber stamps, and failed to monitor the actions of the controlling shareholder, even when resources were being squandered due to tunnelling and empire building.

Following the 1997 financial crisis, however, a nation-wide reform began. Laws were amended to improve corporate governance and reform the chaebols. An outside director system was introduced to improve the monitoring function of company boards. In February 1998, the Listing Act was amended to require all listed firms, excluding the Korean Securities Dealers Automated Quotations(KOSDAQ), to appoint at least one outside director, with outside directors to comprise no less than a quarter of board members by the time of the firm's Annual General Meeting (AGM) in 1999. This means that all listed firms must have a minimum of one outside director, and the number of additional outside members required depends on the size of the existing board. Following the first wave of reforms, focused on streamlining the business practices of chaebols in 1998 and 1999, the Korean government introduced a second wave of reforms, including amendments to the Securities and Exchange Law, in March 2001 and December 2003. These revisions of the Acts stipulate by law the 1998 Listing Act's requirement for outside directors for all listed firms on both the Korea Exchange and the KOSDAQ (except for venture capital companies with an asset size of 100 billion won or less). They specifically require (1) large listed 
corporations to establish an Audit Committee and Appointment Committee under the BOD that is comprised mainly of outside directors, (2) that no fewer than half the board members of large firms should be outside directors, and (3) that large firms listed on the Korea Exchange and KOSDAQ should have at least three outside directors and at least half the board positions should be filled by outside directors.

Owing to these regulatory reforms to board structure and the development of a market for outside directors, listed firms began to appoint outside directors in 1999. Table 1 shows the proportion of outside directors in firms on the Korea Exchange. Table 1 indicates that the proportion of listed firms with at least one outside director increased significantly from 34 percent in 1999 to 62.3 percent in 2000 and to 95 percent in $2007 .{ }^{2}$ Both introduction of the new regulations and the development of a market for outside directors were main reasons for this sharp increase. The table also shows that the most common number of outside directors per firm was two.

Insert Table 1 \& Fig. 1

Figure 1 shows trends in the size of the BOD, the number of outside directors (left axis) and the ratio of outside directors to total board members on the BOD (right axis) between 1999 and 2007. It illustrates that the number of outside directors, compared to total board members, increased significantly over this period of time. The ratio of outside directors to total members on the BOD has continued to increase and reached 0.33 in 2007. This increase reflected the firms' strategic choice to downsize their boards (i.e. the denominator), coupled with the appointment of outside directors (i.e. the numerator) to comply with regulatory requirements.

\footnotetext{
${ }^{2}$ This implies that 5 per cent of firms did not appoint an outside director in 2007, despite the existence of legislation requiring the appointment of at least one outside director. This suggests that these 5 per cent of firms were not in compliance with the law. Such firms might have found it difficult to find an appropriate outside director because the market for outside directors is still underdeveloped or might have been unable to afford to appoint an outside director. Our dataset does not contain information on the reason these 5 per cent of firms were not in compliance with the law.
} 


\section{Research Hypotheses and Estimation Model}

\subsection{Literature Review and Hypotheses Development}

Foreign equity ownership potentially results in technological transfer from the foreign firm to the domestic firm. One way of conceiving of technological transfer is via the transfer of hard (blueprints, machinery) and soft (management, information) technologies (Mishkin, 2006). The transfer of hard technology should stimulate productivity by generating efficiency gains in the organization of inputs within the firm. The transfer of soft technologies should give management additional expertise to rearrange inputs in the firm in more efficient ways resulting in productivity gains.

Another way of conceiving of technological transfer resulting from foreign equity ownership is via transfer of generic and specific knowledge. Hard and soft technologies do not map directly to generic and specific skills. Generic and specific knowledge can stem from both hard technologies, such as a piece of equipment, and soft technologies, such as management skills and quality systems. Foreign investors can reduce the cost of learning and upgrading by assisting to identify, and implement, systems that are more efficient via transfer of general knowledge. Firms can obtain information via the transfer of specific knowledge from foreign equity partners, which they could not otherwise obtain at arm's length because of weaknesses in the policy environment or incentives for internalization (Djankov \& Hoekman, 2000).

H1: Increased foreign equity ownership has a positive effect on firm productivity. 
The extent to which the technological transfer resulting from foreign equity ownership is effective will depend on the firm's capability to absorb that technology (Markusen, 1995). Firms with better corporate governance arrangements will be better placed to absorb technological transfer from foreign equity ownership for the following reasons. First, firms with better corporate governance will have more transparent decision-making processes. The reason is that in firms with better corporate governance, managers will be more accountable for the decisions which they make. Improved corporate governance limits potential for conflict of interest and improves the disclosure of information. Increased disclosure of information makes it easier for stakeholders to assess, and oversee, management and keep management accountable. This, in turn, puts pressure on management to utilize technological transfer in the most effective manner, resulting in efficiency gains.

Second, as one metric of corporate governance, it is argued that outside directors are more independent than their inside counterparts. The reason is that their future career does not depend on the professional advancement of their board colleagues as much. Inside directors might be less willing to put pressure on management because they fear it might hurt their own career prospects through creating enemies within the firm, particularly if there are adverse short-term side effects such as job losses. Outside directors, on the other hand, will be less concerned with internal politicking and can exert pressure on management to make decisions designed to put the technological transfer from foreign ownership to best use.

Third, Fama and Jensen (1983) argued that outside directorships is a sign of managerial quality and outside directors should be regarded as having outstanding managerial expertise. If so, outside directors bring a higher quality of expertise and 
information to the firm, which inside directors lack. Higher levels of managerial expertise can be used to employ technological transfer in better ways.

Fourth, firms with better corporate governance have been shown to invest more in R\&D as well as in training their workforce (Hillier, Pindado, de Queiroz \& de la Torre, 2009). The reason is that high investment in $R \& D$ is a high risk-high return strategy that is attractive to stockholders because they expect a positive effect on performance and can reduce risks by diversifying their investment portfolio. On the other hand, managers may be reluctant to invest in $R \& D$ because innovative projects have high failure rates and do not yield short-term returns. Given that top managers' position and wealth are tied to a firm's performance, risky R\&D projects carry with them an employment risk which cannot be diversified away (Baysinger, Kosnik \& Turk, 1991). Firms with high levels of R\&D and a trained workforce are better equipped to be able to fully absorb the benefits from technological transfer associated with foreign ownership.

H2: Liberalising equity ownership will have a stronger positive effect on productivity in firms with better corporate governance than with poor corporate governance.

Trade liberalisation can also have a positive effect on TFP through a learningby-exporting effect (see eg. De Loecker, 2007; Takii, 2005; Fernandes, 2007; Baldwin \& Gu, 2004 and references therein). First, export orientation enables firms to leverage their existing capabilities across countries and create scale economies otherwise not available domestically. Second, firms may learn about new technologies by exporting to knowledgeable buyers who share product designs and production techniques. Third, participation in export markets brings firms into contact with international best practices, which fosters learning and productivity growth. Fourth, participation in export markets may provide incentives to improve 
efficiency because of the intensity of international competition. International competition promotes innovation, which, in turn, generates productivity growth. Innovation, in this context, is the implementation of a new or significantly improved product (goods or service) or process, a new marketing method or a new organizational method in business practices, workplace organization or external relations. Through these changes, more value can be added from a stock of inputs, meaning that productivity is improved.Thus, we have our third hypothesis:

\section{H3: Increased exports have a positive effect on firm productivity.}

Heterogeneous firm trade models suggest that internationalisation has a positive effect on the productivity of some firms, while simultaneously forcing other firms to exit the market (see eg. Melitz, 2003). While one would expect that exporting and investing in productivity are complementary activities, it remains that exporting activity also makes firms more susceptible to international demand shocks, meaning that exporting activity is an additional source of uncertainty for the firm. There are several channels through which corporate governance might affect the relationship between export activity and firm performance. First, entrenched managers in firms with poor corporate governance could be benefiting from a 'quiet life'. The 'quiet life' notion suggests that managers in firms with poor corporate governance are unwilling to undertake the actions needed to benefit from the increased intensity of international competition. Thus, the causal relationship between exporting and productivity will be weakened. Moreover, managers benefitting from a 'quiet life' are more likely to be non-responsive to a shock that requires action to be taken, meaning that their firms would be ill equipped to deal with uncertainty in export markets, relative to firms with good corporate governance. Second, firms with poor corporate governance have been found to dissipate cash quickly in ways that reduce operating 
performance (Dittmar \& Mahrt-Smth, 2007). At the same time, firms' financial constraints play an important role in how firms react to trade liberalization (Manova, 2008). Managers in firms with poor corporate governance might have financial constraints, which make them unable (even if they are willing) to respond to international demand shocks (Amore \& Zaldokas, 2011). Amore and Zaldokas (2011) find evidence consistent with both the 'quiet life' notion that managers in firms with poor governance are unwilling to take actions needed to address increase competition in export markets and that poor governance exacerbates financial constraints that hinder the ability of a firm to react to shocks following entry into the export market.

A third factor is that productivity growth will be higher in exporters that develop the absorptive capacities to take advantage of productivity gains associated with innovation. As discussed above, improved corporate governance, including a higher proportion of outside directors, is correlated with investment in R\&D. Firms with better corporate governance will be more likely to invest in R\&D and develop absorptive capacities needed to take advantage of exporting. Given these arguments, we suggest a fourth hypothesis:

H4:Increased exports will have a stronger positive effect on productivity in firms with better corporate governance than in firms with poor corporate governance

\subsection{Estimation Model}

To test our research hypotheses, we consider the following unobserved effects model with an interaction variable.

$$
\begin{aligned}
\text { TFP }_{i t}= & \alpha \text { Governance }_{i t}+\text { SGlobalisation }_{i t}+\psi \text { Governance }_{i t} \times \text { Globalisation }_{i t}+ \\
& +\boldsymbol{\mu}_{s}+v_{i}+\mathbf{x}_{i t}^{\prime} \boldsymbol{\beta}+\varepsilon_{i t}
\end{aligned}
$$

Here $i$ indexes firms from 1 to $N$ and $t$ indexes time periods (years) from 1 to $T$. TFP, Governance and Globalisation refer respectively to firm total factor productivity, corporate governance and globalisation activities through liberalising equity ownership 
and exports. $\alpha$ and $\psi$ respectively capture the effect of corporate governance and its interaction with globalisation activities, which are of primary interest in this research. The year-specific effect is measured by $\sum_{s=1}^{T} \boldsymbol{\mu}_{s} \cdot 1[t=s]\{1[t=s]\}_{s=1}^{T}$, where the indicator function of [ ] is one if the condition of [ ] is satisfied and zero otherwise. While we are not directly interested in the estimated coefficients of time-specific variables, yearspecific variables capture effects that are specific to the period in which they occur but common to all firms, including various macroeconomic and political shocks. $v_{i}$ captures time invariant unobserved firm-specific effects. The firm-specific unobservable effects control for managerial style and/or work environment. For example, business group LG in Korea emphasises 'harmony' as its work culture, whereas Samsung stresses 'organisational power' and Hyundai a 'can do' approach. Further to this standard estimation model, following Cornwell, Schmidt, and Sickles' (1990), we also include a time trend to capture the evolving nature of productivity.

$\boldsymbol{\beta}$ represents a vector of coefficients associated with a vector of time-varying $\boldsymbol{\beta}$ observed regressors at the firm level, $\mathbf{x}_{i t}^{\prime}$. The specific choice of controls is based on what previous studies suggest are factors likely to be correlated with firm productivity. $\mathbf{x}_{i t}$ includes investment in R\&D (McGuckin, Streitwieser \& Doms, 1998), ownership concentration (Syverson, 2004), human capital and the quality of the workforce (Doms, Dunne \& Troske, 1997), the age of the firm as well as the regulatory environment in which the firm operates (Brown, Earle \& Telegdy, 2006).

We briefly discuss the expected signs on the control variables. Investment in $R \& D$ creates valuable knowledge which can be expected to have a positive effect on productivity growth. Most studies, at least since the 1990s, find that investment in R\&D has a positive effect on productivity (see eg. Dilling-Hansen et.al. 1999). 
The relationship between industry concentration and TFP is unclear. On the one hand competition can induce firms to innovate, stimulating TFP and forcing inefficient firms to leave the market. On the other hand, in contrast to competitive firms, firms with market power can earn supra-normal profits and, as such, have more accumulated resources for investment in $R \& D$ than competitive firms.

The relationship between firm age and productivity is expected to be nonlinear. New firms enter the market with relatively low productivity levels. In order to survive, they need to catch up with existing firms, resulting in high productivity growth for surviving young firms due to both learning and selection effects. Over time productivity reaches a maximum and then starts to decline, possibly reflecting an inertia effect in which older firms are less flexible or innovative (de Kok et al., 2006).

Labour economists consider that human capital is a core part of improving TFP. Better human capital enables the firm to develop/absorb new technologies easier, thus promoting productivity improvements. Poorly regulated markets can create incentives that reduce TFP (Syverson, 2004; Brown et al., 2006). Entry barriers, for example, induce firms to be complacent without improving TFP.

\section{Data and Measurement of Dependent Variable}

We employed longitudinal data for publicly traded Korean firms over the period 1990-2007. The three key variables of interest are estimated productivity, which is the dependent variable, outside directors, which is a proxy for corporate governance, and foreign equity ownership and exports, which are both proxies for globalisation. Data for the estimation of productivity were collected from the Japan Center for Economic Research (JCER) database and the Korea Listed Companies Association (KLCA), whereas data for the independent variables are largely from the KLCA database. 


\subsection{Productivity as the Dependent Variable}

The JCER database provides gross output, intermediate inputs, labor and capital stock in real values. Gross output, intermediate inputs and capital stock are in million won and converted into 1990 values as a base using the appropriate price index, including intermediate goods and the material deflator provided by the Bank of Korea (BOK). Labor inputs, in thousand-hours calculated by the number of employees, were obtained from each firm's financial statements and industry average labor hours were obtained from the Monthly Labor Survey of Korea, Ministry of Labor and the Korea Information Service (KIS).To calculate capital costs, the database used interest rates from the BOK, own capital ratio from KIS (financial statement)and deflators for building and structure, machinery, tools and vehicles from the BOK. If a company was delisted in a particular year, that company was not included in the database in subsequent years. Thus, the number of listed firms varied on an annual basis. We included industrial firms only. There were approximately 390 companies in our sample which left us with around 7,000 firm-year observations in the baseline estimates. In addition, we obtained information about electricity and water energy costs from the KLCA database. To make them consistent with JCER data, the data from the KLCA were deflated using the production price index for fuel energy provided by the $\mathrm{BOK}$.

Table 2 presents data on the average value of outputs and aggregate inputs. Table 2 indicates that the natural logarithm of average output for listed firms increased over the sample period: from 11.21 in 1990 to 12.11 in 2007. The table also shows that Korean listed firms reduced their labor intensive production, due mainly to 
greater use of capital. Firms' use of labor has continued to decline, while their use of capital has increased before declining to some extent since 2000. The pattern of water and energy use by firms was similar to that of capital use, and the use of intermediate goods continued to increase over the same period.

\section{Insert Table 2}

To calculate productivity we follow the following two steps. First, we identify parameters in an estimation model for the linearised (Cobb-Douglas) production function suggested by Olley and Pakes (1996) and Levinsohn and Petrin (2003). This entails selecting a proxy variable to correct for simultaneity bias. Olley and Pakes (1996) use firm investment to correct the simultaneity bias between the input choices of firms and privately known productivity. However, using investment for this purpose is potentially problematic given that investment is lumpy, which may bias annual estimates of productivity. Levinsohn and Petrin (2003) suggested employing intermediate inputs, such as fuel and energy, to control for that part of productivity observed by the firm's decision maker and correlated with input choice. This overcomes the lumpiness problem caused by inverting the investment function as in Olley and Pakes (1996).

We used the Levinsohn and Petrin estimator in all benchmark estimations, while the Olley-Pakes estimator, coupled with the fourth order polynomial expansion method, was employed as a robustness check. For the Levinsohn and Petrin method, the natural $\log$ of labor was used as a freely-variable input, the natural log of electricity was employed as the proxy variable and the natural log of capital stock was employed as the state variable. The dependent variable in this model specification is the natural $\log$ of gross output, proxied by the natural log of total sales in real terms. Coefficients for the freely variable input, proxy and state variables were obtained via 
GMM estimation with contemporaneous natural log of capital and lag-one of the proxy variable as instruments. Second, armed with the estimated parameters from the first stage, we calculated the SIC 4-digit industry-demeaned productivity level following the method suggested by Van Biesebroeck (2007).

\subsection{Corporate Governance and Globalisation Proxies}

The KLCA database provides a wide range of information including balance sheet, income statement, stock price, auditor's opinion, and general information about stocklisted and KOSDAQ-listed corporations. Our data set excluded KOSDAQ-listed firms and financial companies to increase comparability between firms.

The KLCA database provides information on both the numbers of outside directors and total board members from 1999. We included outside directors who had their own office in a firm as well as those who did not have their own office, although the majority of outside directors are external. The database provides information on the percentage of equity owned by foreigners. Domestic firms' exports are also obtained from the KLCA database in domestic currency.

Corporate governance was proxied by the appointment of outside directors, combined with the ratio of outside directors to board members. We measure the extent of a firm's globalisation by (1) foreign ownership, calculated by the proportion of total issued stock owned by foreign investors, and (2) exports, denoted as exports as a percentage of total sales.

Table 3 shows that both the average number of outside directors and the proportion of outside directors on the board have increased since 2000 . The average number of outside directors (the ratio of outside directors on the BOD) for listed firms has increased from $1.35(0.21)$ in 2000 to $2.22(0.35)$ in 2007 . This increase was due 
largely to changes in legal requirements, including the Listing Act and the Securities and Exchange Acts described above.

Table 3 also shows that foreign equity ownership in domestic firms in 2007 was around five times higher than in 1990, due largely to liberalised foreign ownership and improvements in the reputation of Korean firms in the global market. The average listed firm's ratio of exports to total sales also increased until 2000, before declining marginally since the mid 2000s. This decline may reflect resurgence in protectionism by Korea's major export markets, including the United States, in response to the deterioration in their current account balances.

\section{Insert Table 3}

\section{Results}

\subsection{Benchmark Estimation: Without Interaction Variables}

Firm TFP in all specifications, except the robustness checks, was estimated by the Levinsohn and Petrin estimator using GMM. Table 4 presents the baseline estimates. The coefficients on mean-centred outside directors (Outside Director $(O D)$ _C) in Table 4 show the relationship between outside directors, measured by the demeaned proportion of outside directors to total board members, and TFP. The estimation results suggest that the proportion of outside directors is positively and significantly associated with TFP, irrespective of model specification. Models (1) and (2) largely reflect the 'total' amount of association between outside directors and productivity, as the models have no (time-varying) control variables. In other words, it shows the direct effect of outside directors as well as the indirect effect through the omitted intervening variable. Thus, it may capture a spurious association.

Insert Table 4 
Models (3) and (4) include a mean-centred foreign ownership variable and other time-varying control variables. Model (7) shows a model including both meancentred foreign equity ownership and mean-centred exports. The coefficients on outside directors in Models (3), (4) and (7) continue to be statistically significant even when we control for other time-varying variables. A similar outcome was found when we used the ratio of exports to sales in Models (5) and (6), although the magnitude of the estimated coefficient was smaller than that for foreign ownership. These findings are consistent with $H 1$ and $H 3$. To compare the economic effects of foreign investment and exports, we standardised these variables in Model (7). These standardised coefficients represent the estimated increase in population mean TFP when the variables increase by one standard deviation. A one standard deviation increase in foreign equity ownership increased mean TFP more than a corresponding increase in exports by almost a factor of two and a half. Most other variables are not significant although industry concentration, proxied by the Hirfindahl-Hirschman index (HHI), R\&D and age variables are marginally significant.

\subsection{Separating Total Effects with Interaction Variables}

Use of mean-centred variables is recommended to analyse interaction variables (see eg Aiken \& West, 1991). This is mainly to simplify the interpretation of the marginal effects of the interaction between continuous variables. The results in Table 5 examine the interaction effects between mean-centred outside directors and the meancentred share of foreign ownership in issued stocks (Models 1-2) and the interaction between mean-centred outside directors and the mean-centred ratio of exports to sales (Models 3-4). Model (5) includes both mean-centred foreign ownership and the meancentred ratio of exports variables. 
The results in Models 1, 2 and 5 show that mean-centred foreign ownership is significant, consistent with $H 1$. The interaction between mean-centred foreign ownership and the mean-centred outside director variable is also significant at the 1 percent level. Statistics for the $F$-test for the joint null of the outside directors and the interaction variables were large enough to reject the null hypothesis of no effect at the 1 percent level. This result is also consistent with $H 2$. The statistical significance of the mean-centred outside director variable remains intact even when we control for the interaction variables.

Based on Model (1) in Table 5, Figure 2_A shows the interaction effect on TFP (Y-axis) for a firm appointed outside director in the highest-quartile (solid line) and lowest-quartile (dashed line) of outside directors scaled by board members when mean-centred foreign ownership deviates from its mean value of 6.8 percent along the $\mathrm{X}$-axis. Figure 2_A suggests that as the share of mean-centred foreign ownership increases, the effect on TFP is improving for firms with outside directors in the highest-quartile. This improvement is represented by the positive slope $(0.387)$ of the solid line. This slope indicates the marginal effect of mean-centred foreign ownership on productivity for a firm with outside directors in the highest-quartile. The calculated standard deviation of this slope using the formula explained at the bottom of Table 2_A suggests that the marginal effect of mean-centred foreign ownership for firms with outside directors in the highest-quartile are significant at the 1 percent level. ${ }^{3}$ The solid line also indicates the intercept of 1.169 is the average productivity when foreign ownership reaches its mean value. Using the same method we analyse the marginal effect of mean-centred foreign ownership for firms with outside directors in the lowest-quartile (dashed-line). The negative slope of the line is due to the negative

${ }^{3}$ Refer to Brambor, Clark and Golder (2006) and Aiken and West (1991) for the explanation of the formula. 
mean value $(-13.2 \%)$ of the mean-centred outside director variable. Similar to firms with outside directors in the highest-quartile, the marginal effect of mean-centred foreign ownership on productivity is significant. In contrast to firms with outside directors in the highest-quartile, however, the marginal effect of foreign ownership on productivity is attenuated as the export ratio increases in the lowest-quartile firms.

The difference in TFP increases in Figure 2_A is due to (indirect) managerial effects largely in conjunction with liberalisation in foreign equity ownership as indicated by the estimated coefficient of the interaction variable. Our result supports Kose, Prasad and Terrones' (2008) findings and confirms the estimation results without interaction variables (i.e., Model (7) in Table 4). The magnitude of the estimated coefficient of foreign ownership in Table 5, however, is smaller than that in Table 4. This is because the total (positive) effect of foreign ownership is divided into (positive) direct and (positive) indirect effects. The positive sign of the estimated coefficient indicates that foreign investors' equity investment is associated with improved allocative efficiency, spillover effects and better access to new technology (Blomstrom, Kokko \& Zejan, 2000). More importantly, the significance of the interaction variable between the mean-centred foreign ownership and mean-centred outside director variables illustrates that the positive direct effect of foreign investment on TFP was reinforced by a positive indirect effect occurring through managerial vigilance, consistent with $H 1$ and $H 2$.

Models (3) and (4) in Table 5 report the relationship between exports interacted with corporate governance and TFP. The results in Models (3) and (4) show that the interaction effect of exports and outside directors is not significant at the conventional level, whereas the direct effect of exports is significant at the 1 percent level. Both the solid- and the dashed-lines in Figure 2_B also show that effects of 
exports on productivity are relatively insignificant. Using the same formula for the marginal effect of foreign ownership, calculated standard deviations for both lines indicate that the marginal effect for exports is not statistically significant. This result suggests that the improvement in TFP resulting from learning-by-exporting in the global market associated with exports is sizeable, while the marginal contribution of good governance through exports to TFP is limited. These findings are robust even when we include both mean-centred foreign ownership and mean-centred exports variables in Model (5), which is consistent with $H 3$. Figure 2_B suggests that the effect of increasing exports on TFP between firms with outside directors in the highest- and lowest-quartile parts of the distribution changes little when a firm increase its exports. Irrespective of the percentage of exports in sales, the effect of an increase in exports on TFP for firms with outside directors in the highest-quartile remains greater than that for firms with outside directors in the lowest-quartile, supporting the prediction in $\mathrm{H} 4$.

Insert Table 5 \& Figure 2_A and Figure 2_B

\subsection{Chaebol Affiliates versus Independent Firms}

Schulze et al. (2003) highlighted the importance of ownership dispersion among the directors of private family firms. Given the importance of chaebols and power of the controlling shareholder of chaebols (Chang \& Hong, 2003), we conjecture that the productivity effect of globalisation may be more attenuated in chaebol affiliates than in independent firms. In the past, the controlling shareholders of chaebols exercised power directly over the firm's production decisions, as well as indirectly by controlling the management of affiliates by holding tenured positions without legal responsibility. Excessive investment for building a business empire might have resulted in tunnelling and inefficiency (Chang, 2003; Bae, Kang \& Kim, 2002; Joh, 2003). Many of the amendments to laws following the 1997 crisis sought to rectify 
this problem, including a legal requirement for the controlling shareholder to be a registered board member and the strengthening of minority shareholder rights.

To examine any difference between chaebol affiliates and stand-alone firms, we generated a binary variable, which is equal to 1 if a firm belongs to the Korea Fair Trade Commission-designated chaebols and zero otherwise. Table 6 reports that the binary variable is negative and significant at the 1 percent level regardless of model specification. The results also indicate that the interaction between the chaebol dummy variable and outside director variable is negative, although statistical significance differs depending on model specifications. To investigate $H I$ and $H 3$ for chaebols, we generated two interaction variables. One is the interaction between the outside directors, foreign ownership and chaebol variables $(O D \times$ Foreign $\times$ Chaebol $)$. The other is the interaction between the outside directors, exports and chaebol variables $(O D \times$ Exports $\times$ Chaebol $)$. The positive sign on the coefficient on the $O D \times$ Foreign variable in Column (4) in Table 6 implies that foreign ownership intensifies the effect of outside directors for listed companies. The negative sign on the coefficient on the $O D \times$ Foreign $\times$ Chaebol variable in Column (5), therefore, suggests that this positive effect of foreign ownership is attenuated for firms belonging to chaebols. Similarly, the positive effect of exports is attenuated for firms belonging to chaebols as the coefficient on $O D \times$ Exports $\times$ Chaebol has a negative sign .

\footnotetext{
Insert Table 6

\subsection{Treatment of Endogeneity Bias}

We considered three possible causes of endogeneity problems. The first was the correlation between the included regressors and unobserved firm-specific factors, and this was addressed by inclusion of the firm-effect variables. An example of this
} 
correlation would be where a particular managerial style or firm image either attracts or deters foreign investment and overseas demand for the firm's outputs as well as TFP. The second and third concerns were estimation bias caused by self-selection and reverse causality. Self-selection bias arises either from the estimation of the TFP and/or from the estimation of Equation (1). The former can be addressed through employing either the Olley and Pakes (1996) or Levinsohn and Petrin (2003) method.

Foreign investors' investment decisions may depend on a firm's past productivity. In this context, Gourinchas and Jeanne (2007) provide evidence against such reverse causality by showing that, among emerging economies, net capital flows are negatively correlated with productivity growth. One may also be concerned with potential endogeneity associated with reform in the labour market. For instance, if labor laws were also simultaneously revised, generating a more flexible market place for talent, foreign firms may find it more attractive to invest in Korea. The changes in labor laws could also have a direct effect on TFP that we are picking up as the effect of outside directors. The evidence, however, does not support the existence of a pent up effect of reform in labour market. In fact, average growth rate of labour productivity in the manufacturing sector following the Asian financial crisis dropped slightly although labor productivity in the service sector improved (Pyo et al., 2006).

A remaining concern is the endogeneity problem associated with the appointment of outside directors. In terms of the estimation of Equation (1), the appointment of outside directors in Korea was largely driven by legal requirements. However, we observe in Table 1 that a large portion of firms did not meet the 25 percent requirement and some firms did not appoint outside directors at all. This finding may suggest that a firm's choice of appointing outsiders also depends on productivity, whereby reverse causality causes an endogeneity problem. Instead of an 
ad hoc type regression with a lagged (suspected) endogenous variable, we used the instrumental variable method. The outside director variable was treated as endogenous. The excluded instrument variables were the end of previous year's board size and asset size. We chose these two variables for the following reasons. First, the regulation of board structure by the amended Listing Act 1998 stipulates that all listed firms are to appoint at least 25 percent of board members as outside directors. Thus, the size of the board directly affects the appointment of outside directors. Traditionally, board membership in Korea is largely determined by seniority-based promotion rather than being performance-based (Kim \& Briscoe, 1997). Hence, board size is directly associated with the appointment of outside directors, but not directly associated with productivity. Second, the amendments to the Securities and Exchange Law, in March 2001 and December 2003 require that outside directors constitute at least 50 per cent of board members in large firms. Definition of a large firm, here, depends on the size of the firm's assets. We used natural logarithm of asset size to mitigate skewness.

The results reported in Table 7 indicate that endogeneity bias is not a major concern. The coefficient on the outside director variable remains significant irrespective of model specification and the magnitude of the coefficient on the outside director variable is larger with the instrumental variable estimation. Our excluded instrument variables have the expected signs and are statistically significant in the first stage. The first-stage F-statistics are all high and statistically significant, satisfying the Stock and Yogo (2005) test for avoiding weak instrument bias

Insert Table 7

\subsection{Further Robustness Checks}

To examine possible serial correlation over time, we re-estimated the baseline model with interaction variables after explicitly considering the first-order autoregressive 
model. Our results (not reported) suggest that the effect of the interaction between outside directors and foreign ownership remained significant regardless of model specification. The $F$-statistic for the joint null of outside directors and its interaction with foreign ownership is also large enough to reject the null hypothesis at the conventional level. By contrast, the interaction between outside directors and exports was not significant, although the export variable itself, given other control variables, was significant.

We also explicitly considered a binary variable, defined as one if the year was 1997 or 1998 and zero otherwise, to capture the effect of the financial crisis. The estimated coefficient of this crisis variable from the baseline estimation with interaction variables was significant for two out of the six model specifications. However, the statistical significance of the interaction variables across the models remained similar to the baseline estimation, although the magnitude of the coefficients fell by a small margin.

As a robustness check on our baseline estimation using the Levinsohn and Petrin (2003) method, we also estimated TFP using the Olley and Pakes (1996) estimator (with minor modification), which inverts the investment function. ${ }^{4}$ Our results (not reported) suggest, similar to the baseline specification reported in Table 5, that all interaction variables remained significant at the conventional level for $O D \times$ ForeignOwn (and at the 10 percent level for $O D \times$ Exports). Foreign Ownership was significant irrespective of model specification, whereas the robustness of the

\footnotetext{
${ }^{4}$ Our estimates do not consider the potential estimation bias caused by a firm's self-selective exit due to absence of exit information from our databases. The inverted investment function gives an observable expression for productivity in the production function. First, we ran a regression to estimate the coefficient on the natural $\log$ of labor coupled with intermediate goods, measured by water and energy costs, and the coefficient of capital by the combination of investment and capital for fourth order expansion. We also tested the third order expansion, but the estimates did not change.
} 
Exports variable was sensitive to model specification. These findings again show that the direct effect of the appointment of outside director/s itself on TFP could be open to debate, but its indirect effect (i.e. managerial vigilance) when interacted with globalisation (foreign ownership or exports) is important, consistent with $H 2$ and $H 4$.

\section{Managerial Implications}

Our main finding is that foreign ownership results in a greater productivity increase than exports. We also find that both the effect of foreign ownership and exports on productivity is more pronounced in firms with good governance than poor governance. Interestingly, this positive effect of foreign ownership is accelerated significantly by good governance when foreign ownership increases, but the acceleration associated with increased exports is only at the margin. This finding is consistent with the different nature of the globalisation process via foreign equity ownership and exports in that foreign equity ownership is more directly associated with managerial practice (i.e., it induces higher effort from managers) than the arms' length transaction of exports. This raises the issue of the ease with which managers may increase foreign equity to boost productivity and, related to this, the extent to which they would want to increase foreign equity taking a broader perspective.

As discussed above there have been virtually no restrictions on foreign ownership in Korea since the Asian financial crisis. The Foreign Investment Promotion Act in 1998 opened up Korea's industries to foreign investment and established several institutions to facilitate foreign investment. Most notable among these were Invest KOREA and the Office of the Foreign Investment Ombudsman, both of which are affiliated with KOTRA, the Korea Trade-Investment Promotion Agency. As a result foreign direct investment in Korea has increased fivefold since the Asian financial crisis. The ability of management to attract foreign investment 
depends on the home country and the sector in which they are located. The United States is the single largest source of foreign investment (19 per cent), followed by Japan (18 per cent). The European Union as a whole accounts for about 40 per cent of investment in Korea, with the Netherlands (13 per cent) being the single largest investor in Korea from Europe. Manufacturing accounts for about 40 per cent of foreign investment in Korea, concentrated in chemicals and electronics (Ahn, 2008).

Despite the recent surge in foreign investment in Korea, Korea still rates relatively low in terms of preferred destinations in which to invest. In a 2012 Bloomberg survey of the 50 best countries in which to invest, Korea ranked $29^{\text {th }}$, behind other Asian countries such as Hong Kong (first), Japan (seventh), Singapore (ninth) and China $\left(19^{\text {th }}\right)$ (Chosun Ilbo, 2012). Foreign investors in Korea have registered a range of difficulties, with the most common being in the areas of labormanagement problems, taxation and tariff related grievances and custom and traderelated grievances (Ahn, 2008). The United Nations Conference on Trade and Development has placed emphasis on global investment aftercare and related advocacy measures as an effective vehicle to improve international investor relations (Ahn, 2008). Clearly addressing many foreign investor grievances lie beyond the scope of individual managers and depend on government action. However, others, such as the labor-management climate lie within the scope of management to address. Indeed, there have been improvements in labor-management culture which has seen a decline in complaints concerned with labor-management relations in Korea.

From a broader perspective, managers might not want an increase in foreign investment. Following an initial surge in foreign investment after the relaxation of controls on foreign equity in the aftermath of the Asian financial crisis, this is what happened in the late 1990s in Korea. There was resistance to further foreign 
investment because Korean managers were concerned about ceding control to foreigners (see eg. Kirk, 1999). Intuitively, with an increase in foreign ownership beyond a certain threshold level (i.e., typically 10 percent), managerial control will move the incumbent to the multinational. Bloom and Van Reenen (2007) demonstrate that management practice is a material factor determining TFP. To the extent that Korean managers are concerned with losing control to foreign interests, this should be a powerful threat to the incumbent management to change management practice.

An increase in foreign ownership can also act as a catalyst for the board to improve TFP by providing resources (Pfeffer \& Salancik, 1978). The role of U.S investors in Korea since the 1997 crisis has also been important. U.S. investors are usually more concerned about the activities that the board undertake to improve firm value than any other investors. The portion of professors appointed as outside directors between 2002 and 2006 ranged between 20-22 percent, which is the second largest following managers/CEO sat 32-33 percent (Min, 2013a). Most professors in Korea obtained their PhD degrees in the U.S. To the extent that the appointed outside directors are familiar with the U.S. governance system, the improved governance and foreign ownership can be expected to generate positive interaction effects.

\section{Conclusion}

This paper has examined the relationship between corporate governance, globalisation and firm productivity in Korea, distinguishing between exports and foreign equity ownership as alternative measures of globalisation and using outside directors as a measure of corporate governance. This paper explored the managerial vigilance effect of liberalising equity ownership, arguing that any positive effects of foreign equity ownership on TFP will be enhanced when improved corporate governance leads to a 
better managerial effect. To achieve this goal, we disentangled the effect of the interaction between foreign equity ownership and corporate governance on TFP from the total effects. Exploring real consequences (i.e. effects on productivity) differentiates our paper from most of the extant corporate governance literature that focuses primarily on accounting/financial variables. Moreover, in contrast to existing literature on globalisation and TFP, we also explicitly took account of managerial effects associated with liberalising foreign ownership.

The results based on longitudinal data from Korea, where equity ownership and corporate governance systems have changed significantly since the 1990s, indicate that the positive effect of liberalisation on firm TFP was strengthened by indirect managerial effects when a firm improved its corporate governance arrangements. Our results also indicate that this channelling effect is monotonic in that both the appointment of outside directors and the proportion of outside directors on the board are important in determining the interaction effect. In addition, our findings confirm that the interaction of the managerial effect with increased foreign equity ownership is more significant than interaction with arm's length competition from exports. Therefore, we conclude that liberalising foreign equity ownership (in a small, open economy) is more effective in capitalising on the benefits of corporate governance by generating managerial effects than increasing exports to overseas markets.

Further investigation revealed that the effect of the interaction between indirect managerial incentives and foreign equity ownership was more evident for independent firms than for chaebol affiliates. However, the differences between the interaction variables for the two sets of firms were not statistically significant, implying that this finding is tentative, rather than conclusive. Consideration of the different managerial 
responses to increased foreign ownership between chaebol affiliates and independent firms, if any, is an interesting research question that awaits future research. 


\section{Rerferences}

Aguilera, R.V., and Jackson, G., (2003). The cross-national diversity of corporate governance: Dimensions and determinants. Academy of Management Review,28: 447-65.

Ahn, C.Y. (2008). New Direction of Korea's Foreign Direct Investment Policy in the Multi-track FTA Era: Inducement and Aftercare Services. OECD Global Forum on International Investment, March 27-28, Paris, OECD.

Aiken, L.S., and West, S.G., (1991), Multiple regression: Testing and interpreting interactions, Sage Publications Inc.

Amore, M.D. and Zaldokas, A. (2011). Corporate governance and international trade shocks. Manuscript, Copenhagen Business School.

Amsden, A.H., (1989). Asia's next giant: South Korea and late industrialisation, Oxford University Press, Oxford: Blackwell.

Bae, K-H, Kang J-K., and Kim, J-M., (2002 ). Tunneling or value added? Evidence from mergers by Korean business groups. Journal of Finance, 57: 2695-2740.

Baldwin, J.R. and Gu, W., (2004). Trade liberalisation: Export-market participation, productivity growth and innovation, Oxford Review of Economic Policy, 20: $372-392$

Baysinger, B.D., Kosnik, R.D. and Turk, T.A. (1991). Effects of board and ownership structure on corporate R\&D strategy. Academy of Management Journal, 34: 205-214.

Blomstrom, M., Kokko, A.,and Zejan, M., (2000). Foreign Direct Investment: Firm and Host Country Strategies. Macmillan Press, London. 
Bloom, N., and Van Reenen, J., (2007). Measuring and explaining management practices across firms and countries. Quarterly Journal of Economics, 122: $1351-1408$.

Brambor, T., Clark, W.R., and Golder, M., (2006). Understanding interaction models: Improving empirical analysis, Political Analysis, 14:63-82.

Brown, D.J., Earle, J.S., and Telegdy, A., (2006). The productivity effects of privatisation: Longitudinal estimates from Hungary, Romania, Russia and Ukraine. Journal of Political Economy, 114:61-99.

Chang, S-J., (2003). Ownership Structure, Expropriation, and Economic Performance of Group-affiliated Companies in Korea. Academy of Management Journal, 46: $238-254$.

Chizema, A., and Kim, J., (2010). Outside directors on Korean boards: Governance and institutions, Journal of Management Studies, 47: 109-129.

Choi, J., Park, S. and Yoo, S., (2007). The value of outside directors: Evidence from corporate governance reform in Korea, Journal of Financial and Quantitative Analysis, 42: 941-962.

Chosun Ilbo (2012). Why are politicians silent about foreign investment? Chosun Ilbo (English Edition) April 4.

Cornwell, C., Schmidt, P., Sickles, R.C.,(1990). Productivity frontiers with crosssectional and time-series variation in efficiency levels. Journal of Econometrics,46:185-200.

De Kok, J.M.P., Fris, P. and Brouwer, P. (2006). On the relationship between firm age and productivity growth. SCALES Working Paper H200617.

De Loecker, J., (2007). Do exports generate higher productivity? Evidence from Slovenia. Journal of International Economics, 73:69-98. 
Dilling-Hansen, M., Eriksson, T., Madsen, E. and Smith, V. (1999). The impact of R\&D on productivity: Evidence from Danish manufacturing firms. Manuscript, Danish Institute for Studies in Research and Research Policy.

Dittmar, A. and Mahrt-Smith, J. (2007). Corporate governance and the value of cash holdings. Journal of Financial Economics, 83: 599-634.

Djankov, S. and Hoekman, B. (2000). Foreign investment and productivity growth in Czech enterprises. World Bank Economic Review, 14: 49-64.

Doidge, C., Karolyi, G.A., and Stulz, R.M., (2007). Why do countries matter so much for corporate governance. Journal of Financial Economics, 86:1-39.

Doms, M.E., Dunne, T., and Troske, K., (1997). Workers, wages and technology. Quarterly Journal of Economics, 112: 253-90.

Fama, E. and Jensen, M. (1983). Separation of ownership and control. Journal of Law and Economics, 26: 301-325.

Fernandes, A., (2007). Trade policy, trade volumes and plant level productivity in Colombian manufacturing industries. Journal of International Economics, 71: $52-71$.

Forbes, K.J., (2004). The Asian flu and Russian virus: the international transmission of crises in firm-level data. Journal of International Economics, 63:59-92.

Fukao, K., Inui, T., Ito, K., Kim, Y.G and Yuan, T. (2011). An international comparison of the TFP levels and the productivity convergence of Japanese, Korean, Taiwanese and Chinese listed firms. Journal of Chinese Economic and Business Studies, 9: 127-150.

Girma, S. and Gorg, H. (2004). Outsourcing, foreign ownership and productivity: Evidence from UK establishment data. Review of International Economics, 12: 817-832. 
Gourinchas, P-O, and Jeanne, O. (2007). Capital flows to developing countries: The allocation puzzle. NBER Working Paper \#13602.

Hayakawa, K., Machikita, T. and Kimura, F. (2012). Globalisation and productivity: A survey of firm-level analysis. Journal of Economic Surveys, 26, 332-350.

Heshmati, A. and Kim, H. (2011). The R\&D and productivity growth relationship of Korean listed firms. Journal of Productivity Analysis, 36: 125-142.

Hillier, D., Pindado, J., de Queiroz, V. and de la Torre, C. (2009). The impact of corporate governance on R\&D: An international study. Manuscript, University of Leeds.

Japan Center for Economic Research, (2008). The East Asian Listed Companies Database 2007.

Joh, S.W., (2003). Corporate governance and profitability: Evidence from Korea before the economic crisis. Journal of Financial Economics,68:287-322.

Kim, S., and Briscoe, D.R., (1997). Globalisation and a new human resource policy in Korea: Transformation to a performance-based HRM. Employee Relations, 19(4): 298- 308.

Kim, E.,and Kim, W., (2008). Changes in Korean corporate governance: A response to crisis. Journal of Applied Corporate Finance, 20: 47-58.

Kim, H., and Lim, C., (2010). Diversity, outside directors and firm valuation: Korean evidence, Journal of Business Research, 63: 284-291.

Kim, J. (2013). The effect of corporate taxes on firm productivity in Korea. Korea and the World Economy, 14, 147-172.

Kim, Y-G. and Ito, K. (2013). R\&D investment and productivity: A comparative study of Japanese and Korean firms. RIETI Discussion Paper 13-E-043.

Kirk, D. (1999). Korean companies cooling to foreign investors. New York Times, July 3. 
Kneller, R., McGowan, D., Inui, T. and Matsuura, T. (2012). Globalisation, multinationals and productivity in Japan's lost decade. Journal of the Japanese and International Economies, 26: 110-128.

Kose, A.M., Prasad, E.S., and Terrones, M.E.,(2008). Does openness to international financial flows raise productivity growth? IMF Working Paper \#242.

Levinsohn, J., and Petrin, A., (2003). Estimating production functions using inputs to control for observables. Review of Economic Studies, 70:317-341.

Manova, K. (2008). Credit constraints, equity market liberalizations and international trade. Journal of International Economics, 76, 33-47.

Markusen, J.R., (1995). The boundaries of multinational enterprises and the theory of international trade. Journal of Economic Perspectives, 9: 169-189.

McGuckin, R.H., Streitwieser, M., and Doms, M., (1998). Advanced technology usage and productivity growth. Economics of Innovation New Technology, 7:1-26.

Melitz, M. (2003). The impact of trade on aggregate industry productivity and intraindustry reallocations, Econometrica, 71(6): 1695-1725.

Min, B.S., (2013 a). The effect of outside board members on corporate sustainability in Korea, Journal of Asia Pacific Business, (forthcoming).

Min, B.S., (2013 b). Evaluation of board reforms: An examination of the appointment of outside directors, Journal of the Japanese and International Economies, (forthcoming)

Min, B.S., and Verhoeven, P., (2013). Outsider board activity, ownership structure and firm value: Evidence from Korea, International Review of Finance, $13(2): 187-214$ 
Mishkin, F.S., (2006). The Next Great Globalisation: How disadvantaged Nations Can Harness their Financial Systems to Get Rich. Princeton, N.J.: Princeton University Press.

Ministry of Trade, Industry and Energy (MOTIE) (2013) http://www.motie.org.kr Nicholas, F. (2003). FDI as a factor of economic restructuring: The case of South Korea. In A. Bende-Nabende (Ed.) International Trade, Capital Flows and Economic Development in East Asia: The Challenge of the $21^{\text {st }}$ Century. London: Ashgate.

Oh, D.H. (2011). Productivity growth, efficiency change and technical progress of the Korean manufacturing sector. Journal of the Asia Pacific Economy, 16: 50-70. Olley, S., and Pakes, A., (1996). The dynamics of productivity in the telecommunications equipment industry.Econometrica,64: 1263-98.

Page, J. (1994), The East Asian miracle: an introduction, World Development, 22, pp.615-25.

Pack, H. and Page, J. (1994), Accumulation, exports and growth in the high performing Asian economies, Carnegie-Rochester Conference Series on Public Policy, No. 40, pp. 199-236.

Peng, W. Rabi S, Bhagat, R. S.,and Chang S-J., (2009). Asia and global business. Journal of International Business Studies, 41:373-376.

Pfeffer, J. and Salancik, G.R., (1978).The External Control of Organisations: A Resource Dependence Perspective. Harper \& Row: New York.

Pyo, H.K., Rhee, K.H., and Ha B., (2006). Estimates of labor and total factor productivity by 72 industries in Korea (1970-2003), paper presented at OECD Workshop on Productivity Analysis and Measurement, Bern, 16-18 October.

Schulze, W.S., Lubatkin, M.H., and Dino, R.N., (2003). Exploring the agency consequences of ownership dispersion among the directors of private family firms. Academy of Management Journal, 46:179-94. 
Stock, J.H., Yogo, Y. (2005) “Testing for weak instruments in IV regression.” In Donald W. K. Andrews and James H. Stock, eds. Identification and Inference for EconometricModels: A Festschrift in Honor of Thomas Rothenberg. Cambridge: Cambridge University Press, 80-108.

Sutcliffe, B. and Glyn, A. (2003). Measures of globalisation and their misinterpretation. In Michie, J. (Ed.) The Handbook of GlobalisationLondon: Edward Elgar.

Syverson, C., (2004). Market structure and productivity: A concrete example.Journal of Political Economy, 112:1181-1222.

Syverson, C. (2011). What determines productivity? Journal of Economic Literature, 49: 326-365.

Takii, S., (2005). Productivity spillovers and characteristics of foreign multinational plants in Indonesian manufacturing 1990-1995. Journal of Development Economics, 76:521-542.

Turner, J. and Kim, Y-C., (2004). Inward Foreign Direct Investment Policy and Practice: an Anglo-Korean Comparison, in Turner, J. and Kim, Y-C. (eds.) Globalisation and Korean foreign direct investment, Ashgate Publichsing Limited, Aldershot.

Van Biesebroeck, J., (2007). Robustness of productivity estimates. Journal of Industrial Economics, 55:529-569.

World Bank (2013) World Development Indicators World Bank: Washington DC. 
TABLE 1: Outside directors in corporations listed on the Korea exchange (\%)

\begin{tabular}{lccccccccc}
\hline & 1999 & 2000 & 2001 & 2002 & 2003 & 2004 & 2005 & 2006 & 2007 \\
\hline $\begin{array}{l}\text { Total Listed } \\
\text { Corporations }\end{array}$ & 100 & 100 & 100 & 100 & 100 & 100 & 100 & 100 & 100 \\
$\begin{array}{l}\text { Firms without } \\
\text { outside director }\end{array}$ & 66.0 & 37.7 & 34.6 & 29.6 & 22.4 & 23.6 & 17.9 & 17.6 & 5.7 \\
$\begin{array}{l}\text { Firms with at } \\
\text { least one outside }\end{array}$ & 34.0 & 62.3 & 65.4 & 70.4 & 77.6 & 76.4 & 82.1 & 82.4 & 94.3 \\
director & & & & & & & & & \\
No. of outside & & & & & & & & & \\
directors per firm & & & & & & & & & \\
$=1$ & 16.4 & 19.0 & 22.5 & 22.8 & 24.1 & 23.5 & 26.9 & 28.1 & 32.4 \\
$=2$ & 10.2 & 27.0 & 28.1 & 30.1 & 32.5 & 31.0 & 32.5 & 29.1 & 33.7 \\
$\geq 3$ & 7.3 & 16.3 & 14.7 & 17.5 & 21.1 & 22.0 & 22.8 & 25.2 & 28.1 \\
\hline
\end{tabular}

Notes: Discrepancies, if any, between the total number at the bottom and in row 3 are due to rounding errors. Compilation was based on the KLCA database. We dropped firms if the size of the BOD is zero. 
FIGURE 1: Trends in the size of the BOD, number of outside directors and ratio of outside directors to total directors on the BOD for listed firms

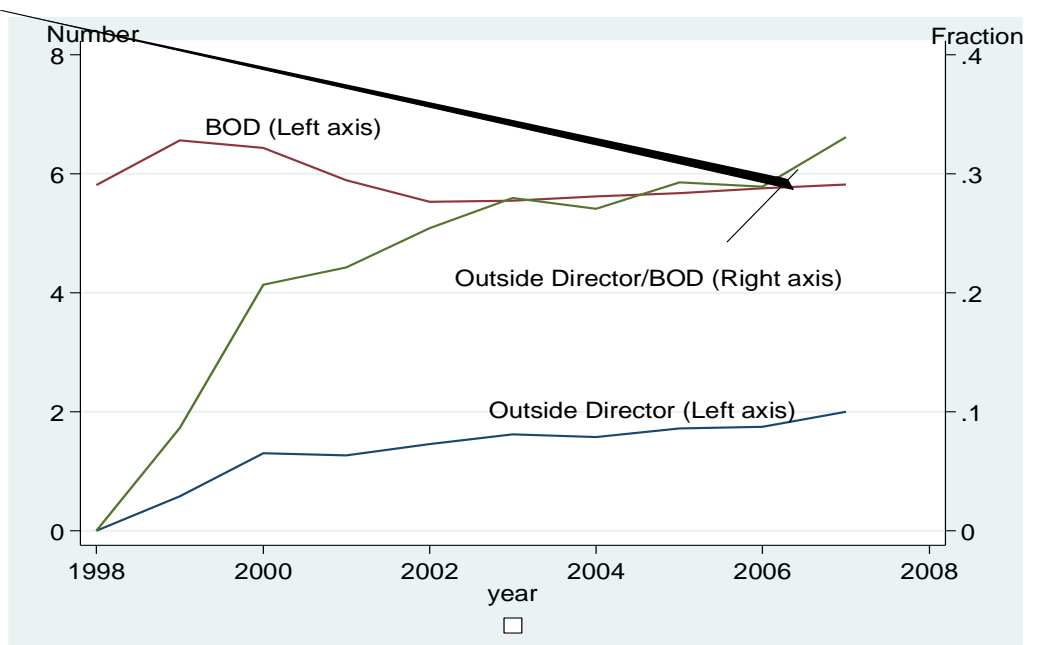

Notes: The left and right axes respectively refer to the number of members on the BOD and the number of outside directors, and the ratio of outside directors/total directors on the BOD (Min, 2013b). 
TABLE 2: Average values of the logarithm of output and production inputs

\begin{tabular}{|c|c|c|c|c|c|}
\hline & 1990 & 1995 & 2000 & 2005 & 2007 \\
\hline $\begin{array}{l}\frac{\text { Ln (output) }}{\text { (standard deviation) }} \\
\{25,75 \text { percentiles }\} \\
\text { [\# of observation] }\end{array}$ & $\begin{array}{l}11.21 \\
(1.30) \\
\{10.2,12.0\} \\
{[372]}\end{array}$ & $\begin{array}{l}11.73 \\
(1.32) \\
\{10.7,12.4\} \\
{[384]}\end{array}$ & $\begin{array}{l}11.94 \\
(1.37) \\
\{10.8,12.3\} \\
{[393]}\end{array}$ & $\begin{array}{l}12.07 \\
(1.49) \\
\{11.1,12.7\} \\
{[413]}\end{array}$ & $\begin{array}{l}12.11 \\
(1.56) \\
\{11.1,12.9\} \\
{[401]}\end{array}$ \\
\hline $\begin{array}{l}\text { Ln (intermediate) } \\
\text { (standard deviation) } \\
\{25,75 \text { percentiles }\} \\
\text { [\# of observation] }\end{array}$ & $\begin{array}{l}11.1 \\
(1.29) \\
\{10.1,11.8\} \\
{[372]}\end{array}$ & $\begin{array}{l}11.4 \\
(1.37) \\
\{10.5,12.1\} \\
{[384]}\end{array}$ & $\begin{array}{l}11.7 \\
(1.37) \\
\{10.8,12.3\} \\
{[393]}\end{array}$ & $\begin{array}{l}11.85 \\
(1.47) \\
\{10.9,12.4\} \\
{[413]}\end{array}$ & $\begin{array}{l}11.92 \\
(1.54) \\
\{10.9,12.7\} \\
{[402]}\end{array}$ \\
\hline $\begin{array}{l}\text { Ln (capital) } \\
\text { (standard deviation) } \\
\{25,75 \text { percentiles }\} \\
\text { [\# of observation] }\end{array}$ & $\begin{array}{l}10.12 \\
(1.44) \\
\{9.1,11.0\} \\
{[372]}\end{array}$ & $\begin{array}{l}10.67 \\
(1.50) \\
\{9.5,11.5\} \\
{[384]}\end{array}$ & $\begin{array}{l}11.13 \\
(1.59) \\
\{10.0,11.9\} \\
{[393]}\end{array}$ & $\begin{array}{l}10.91 \\
(1.67) \\
\{9.8,11.7\} \\
{[413]}\end{array}$ & $\begin{array}{l}10.86 \\
(1.80) \\
\{9.7,11.7\} \\
{[405]}\end{array}$ \\
\hline $\begin{array}{l}\frac{\operatorname{Ln}(\text { labor })}{\text { (standard deviation) }} \\
\{25,75 \text { percentiles }\} \\
\text { [\# of observation] }\end{array}$ & $\begin{array}{l}7.56 \\
(1.18) \\
\{6.6,8.3\} \\
{[372]}\end{array}$ & $\begin{array}{l}7.49 \\
(1.18) \\
\{6.6,8.2\} \\
{[384]}\end{array}$ & $\begin{array}{l}7.25 \\
(1.17) \\
\{6.47,7.89\} \\
{[393]}\end{array}$ & $\begin{array}{l}6.98 \\
(1.30) \\
\{6.15,7.64\} \\
{[413]}\end{array}$ & $\begin{array}{l}6.92 \\
(1.40) \\
\{6.0,7.6\} \\
{[395]}\end{array}$ \\
\hline $\begin{array}{l}\text { Ln (electricity) } \\
\text { (standard deviation) } \\
\{25,75 \text { percentiles }\} \\
\text { [\# of observation] }\end{array}$ & $\begin{array}{l}9.83 \\
(1.91) \\
\{8.5,11.0\} \\
{[365]}\end{array}$ & $\begin{array}{l}9.96 \\
(1.96) \\
\{8.6,11.2\} \\
{[373]}\end{array}$ & $\begin{array}{l}9.66 \\
(2.41) \\
\{8.4,10.9\} \\
{[381]}\end{array}$ & $\begin{array}{l}9.37 \\
(3.68) \\
\{8.3,11.0\} \\
{[387]}\end{array}$ & $\begin{array}{l}9.22 \\
(4.34) \\
\{8.1,11.0\} \\
{[387]}\end{array}$ \\
\hline $\begin{array}{l}\text { Ln (water energy) } \\
\text { (standard deviation) } \\
\{25,75 \text { percentiles }\} \\
\text { [\# of observation] }\end{array}$ & $\begin{array}{l}6.28 \\
(1.78) \\
\{5.1,7.3\} \\
{[293]}\end{array}$ & $\begin{array}{l}6.60 \\
(2.07) \\
\{5.3,8.0\} \\
{[319]}\end{array}$ & $\begin{array}{l}6.62 \\
(1.98) \\
\{5.4,7.9\} \\
{[327]}\end{array}$ & $\begin{array}{l}6.46 \\
(2.0) \\
\{5.1,7.7\} \\
{[335]}\end{array}$ & $\begin{array}{l}6.25 \\
(2.1) \\
\{5.1,7.6\} \\
{[323]}\end{array}$ \\
\hline
\end{tabular}

Sources: JCER database and KLCA database 
TABLE 3: Board structure and globalisation indicators (average values)

\begin{tabular}{|c|c|c|c|c|c|}
\hline & 1990 & 1995 & 2000 & 2005 & 2007 \\
\hline $\begin{array}{l}\text { Outside Directors } \\
\text { (standard deviation) } \\
\{25,75 \text { percentiles }\} \\
\text { [\# of observation] }\end{array}$ & $\begin{array}{l}0.00 \\
(0.00) \\
\{0.00,0.00\} \\
{[530]}\end{array}$ & $\begin{array}{l}0.00 \\
(0.00) \\
\{0.00,0.00\} \\
{[552]}\end{array}$ & $\begin{array}{l}1.35 \\
(1.46) \\
\{0.00,2.00\} \\
{[610]}\end{array}$ & $\begin{array}{l}1.88 \\
(1.63) \\
\{1.00,2.00\} \\
{[656]}\end{array}$ & $\begin{array}{l}2.22 \\
(1.65) \\
\{1.00,3.00\} \\
{[672]}\end{array}$ \\
\hline $\begin{array}{l}\frac{\text { Outside }}{\text { Director/Board }} \\
\text { (standard deviation) } \\
\{25,75 \text { percentiles }\} \\
\text { [\# of observation] }\end{array}$ & $\begin{array}{l}0.00 \\
(0.00) \\
\{0.00,0.00\} \\
{[530]}\end{array}$ & $\begin{array}{l}0.00 \\
(0.00) \\
\{0.00,0.00\} \\
{[552]}\end{array}$ & $\begin{array}{l}0.21 \\
(0.17) \\
\{0.00,0.30\} \\
{[576]}\end{array}$ & $\begin{array}{l}0.30 \\
(0.17) \\
\{0.25,0.40\} \\
{[634]}\end{array}$ & $\begin{array}{l}0.35 \\
(0.16) \\
\{0.25,0.43\} \\
{[668]}\end{array}$ \\
\hline $\begin{array}{l}\text { Foreign Ownership } \\
\text { (standard deviation) } \\
\{25,75 \text { percentiles }\} \\
\text { [\# of observation] }\end{array}$ & $\begin{array}{l}2.03 \\
(6.77) \\
\{0.00,0.02\} \\
{[293]}\end{array}$ & $\begin{array}{l}6.09 \\
(8.54) \\
\{0.25,9.75\} \\
{[332]}\end{array}$ & $\begin{array}{l}5.52 \\
(11.83) \\
\{0.01,4.58\} \\
{[388]}\end{array}$ & $\begin{array}{l}10.75 \\
(15.8) \\
\{0.21,16.9\} \\
{[408]}\end{array}$ & $\begin{array}{l}10.87 \\
(14.64) \\
\{0.48,16.3\} \\
{[400]}\end{array}$ \\
\hline $\begin{array}{l}\text { Export/Sales } \\
\text { (standard deviation) } \\
\{25,75 \text { percentiles }\} \\
\text { [\# of observation] }\end{array}$ & $\begin{array}{l}13.84 \\
(24.21) \\
\{0.00,17.37\} \\
{[368]}\end{array}$ & $\begin{array}{l}21.65 \\
(26.43) \\
\{0.00,34.8\} \\
{[382]}\end{array}$ & $\begin{array}{l}31.02 \\
(28.71) \\
\{4.2,50.2\} \\
{[393]}\end{array}$ & $\begin{array}{l}30.94 \\
(29.8) \\
\{3.1,55.3\} \\
{[413]}\end{array}$ & $\begin{array}{l}29.35 \\
(29.9) \\
\{1.63,56.7\} \\
{[414]}\end{array}$ \\
\hline
\end{tabular}

Source: KLCA database 
TABLE 4: Baseline estimates without interaction variable

\begin{tabular}{|c|c|c|c|c|c|c|c|}
\hline & \multirow[b]{2}{*}{$(1)$} & \multirow[b]{2}{*}{$(2)$} & \multicolumn{2}{|c|}{ Foreign Ownership } & \multicolumn{2}{|c|}{ Exports } & \multirow{2}{*}{$\begin{array}{l}\text { Foreign } \\
\text { ownership } \\
\text { /Exports } \\
\text { (7) }\end{array}$} \\
\hline & & & (3) & (4) & (5) & $(6)$ & \\
\hline \multicolumn{8}{|l|}{ Outside } \\
\hline \multirow[t]{2}{*}{ Director(OD)_C } & $0.046 * * *$ & $0.039 * *$ & $0.034^{* *}$ & $0.034^{* *}$ & $0.039 * *$ & $0.037^{* *}$ & $0.033^{* *}$ \\
\hline & {$[0.001]$} & {$[0.028]$} & {$[0.032]$} & {$[0.029]$} & {$[0.030]$} & {$[0.035]$} & {$[0.031]$} \\
\hline \multirow{2}{*}{\multicolumn{2}{|c|}{ Foreign Ownership_C }} & & $0.072^{* *}$ & $0.071^{* *}$ & & & $0.070^{* *}$ \\
\hline & & & {$[0.050]$} & {$[0.050]$} & & & {$[0.049]$} \\
\hline \multirow[t]{2}{*}{ Exports_C } & & & & & $0.012^{* * *}$ & $0.015^{* * *}$ & $0.012^{* * *}$ \\
\hline & & & & & {$[0.003]$} & {$[0.007]$} & {$[0.004]$} \\
\hline \multirow[t]{2}{*}{$H H I$} & & & & $0.021^{*}$ & & $0.025^{*}$ & $0.023^{*}$ \\
\hline & & & & {$[0.083]$} & & {$[0.073]$} & {$[0.066]$} \\
\hline \multirow[t]{2}{*}{$R \& D$} & & & & $0.468^{*}$ & & 0.480 & $0.487^{*}$ \\
\hline & & & & {$[0.099]$} & & {$[0.111]$} & {$[0.090]$} \\
\hline \multirow[t]{2}{*}{ Firm Age } & & & & $0.138^{*}$ & & $0.112^{*}$ & $0.134^{*}$ \\
\hline & & & & {$[0.065]$} & & {$[0.096]$} & {$[0.069]$} \\
\hline \multirow[t]{2}{*}{ Firm Age2 } & & & & $-0.001 *$ & & -0.001 & $-0.001 *$ \\
\hline & & & & {$[0.068]$} & & {$[0.105]$} & {$[0.073]$} \\
\hline \multirow[t]{2}{*}{ Regulation } & & & & -0.232 & & -0.260 & -0.233 \\
\hline & & & & {$[0.193]$} & & {$[0.191]$} & {$[0.191]$} \\
\hline \multirow[t]{2}{*}{ Training } & & & & 0.007 & & 0.004 & 0.006 \\
\hline & & & & {$[0.409]$} & & {$[0.564]$} & {$[0.427]$} \\
\hline \multirow[t]{2}{*}{ Skilled Labor } & & & & 1.826 & & 1.820 & 1.697 \\
\hline & & & & {$[0.183]$} & & [0.199] & {$[0.204]$} \\
\hline \multirow[t]{2}{*}{ Patent Cost } & & & & -0.262 & & $-0.290 * *$ & -0.310 \\
\hline & & & & {$[0.228]$} & & {$[0.021]$} & {$[0.163]$} \\
\hline Firm fixed effects & Yes & Yes & Yes & Yes & Yes & Yes & Yes \\
\hline Year fixed effects & No & Yes & Yes & Yes & Yes & Yes & Yes \\
\hline $\mathrm{N}$ & 6755 & 6755 & 6263 & 6238 & 6711 & 6278 & 6238 \\
\hline$R^{2}$ & 0.605 & 0.607 & 0.623 & 0.630 & 0.608 & 0.620 & 0.631 \\
\hline
\end{tabular}

Notes: p-values in brackets are based on the Huber-White standard errors.***, ** and $*$ denote significance at the $1 \%, 5 \%$ and $10 \%$ levels respectively. R-squared is adjusted R-squared. Constant value is not shown for brevity. Outside director $(O D)_{-} C$ is the mean-centred value of the percentage of outside directors to total board members. Foreign ownership_C is the mean-centred value of the percentage of foreign-owned shares out of total issued shares. Exports_C is the mean-centred percentage value of exports scaled by sales in home currency. HHI is the Herfindahl-Hirschman index based on the 4-digit (KSIC) industry classification. R\&D is a binary variable with a value of 1 if a firm's R\&D ratio, measured by the ratio of research and development expenditure to sales multiplied by 100 , is in the highest quartile, and zero otherwise. Firm age and Firm age squared respectively show the time lapsed since the firm's establishment and its square. Regulation is proxied by the sum of the government's and public enterprise's ownership as a percentage of total shares outstanding. Training refers to (training cost divided by employee number)/100. Skilled labor is proxied by white-collar employees divided by total number of employees. Patent cost is calculated by $100 *$ (patent cost/sales). 
TABLE 5: Baseline estimation with interaction variables

\begin{tabular}{|c|c|c|c|c|c|}
\hline & \multicolumn{2}{|c|}{ Foreign Ownership } & \multicolumn{2}{|l|}{ Exports } & \multirow{2}{*}{$\begin{array}{l}\text { Foreign Ownership/ } \\
\text { Exports } \\
\text { (5) }\end{array}$} \\
\hline & $(1)$ & $(2)$ & (3) & (4) & \\
\hline \multirow[t]{2}{*}{ Outside Director $(O D) \_C$} & $0.020 * * *$ & $0.019 * * *$ & $0.026 * * *$ & $0.025^{* * *}$ & $0.011^{* * *}$ \\
\hline & [0.001] & {$[0.001]$} & [0.002] & {$[0.006]$} & {$[0.003]$} \\
\hline \multirow[t]{2}{*}{$O D \times$ ForeignOwn_C } & $0.003 * * *$ & $0.003 * * *$ & & & $0.003 * * *$ \\
\hline & [0.001] & [0.003] & & & [0.004] \\
\hline \multirow[t]{2}{*}{ Foreign Ownership_C } & $0.033^{* * *}$ & $0.034 * * *$ & & & $0.036 * *$ \\
\hline & [0.001] & {$[0.008]$} & & & {$[0.011]$} \\
\hline \multirow[t]{2}{*}{$O D \times E x p o r t s \_C$} & & & $0.001 *$ & 0.001 & 0.001 \\
\hline & & & [0.090] & {$[0.101]$} & {$[0.121]$} \\
\hline \multirow[t]{2}{*}{ Exports_C } & & & $0.013^{* * *}$ & $0.016 * * *$ & $0.012 * * *$ \\
\hline & & & {$[0.002]$} & {$[0.002]$} & {$[0.002]$} \\
\hline \multirow[t]{2}{*}{$H H I$} & & $0.018^{* * *}$ & & $0.025 * * *$ & $0.020 * * *$ \\
\hline & & {$[0.004]$} & & {$[0.005]$} & [0.004] \\
\hline \multirow[t]{2}{*}{$R \& D$} & & 0.381 & & 0.468 & 0.397 \\
\hline & & [0.141] & & {$[0.148]$} & [0.139] \\
\hline \multirow[t]{2}{*}{ Firm Age } & & $0.118^{* *}$ & & $0.074 * *$ & $0.086 * *$ \\
\hline & & {$[0.024]$} & & {$[0.021]$} & {$[0.021]$} \\
\hline \multirow[t]{2}{*}{ Firm Age2 } & & $-0.001 * * *$ & & $-0.001 * * *$ & $-0.001 * * *$ \\
\hline & & {$[0.000]$} & & {$[0.003]$} & {$[0.000]$} \\
\hline \multirow[t]{2}{*}{ Regulation } & & $-0.190 *$ & & $-0.327^{*}$ & $-0.250^{*}$ \\
\hline & & [0.089] & & {$[0.100]$} & [0.092] \\
\hline \multirow[t]{2}{*}{ Training } & & $0.010 * * *$ & & $0.002 * * *$ & $0.006^{* * *}$ \\
\hline & & {$[0.005]$} & & {$[0.002]$} & [0.004] \\
\hline \multirow[t]{2}{*}{ Skilled Labor } & & 1.556 & & 1.007 & 0.841 \\
\hline & & [0.394] & & {$[0.337]$} & [0.313] \\
\hline \multirow[t]{2}{*}{ Patent Cost } & & -0.561 & & -0.355 & -0.603 \\
\hline & & {$[0.205]$} & & {$[0.138]$} & {$[0.206]$} \\
\hline Firm fixed effects & Yes & Yes & Yes & Yes & Yes \\
\hline Country fixed effects & Yes & Yes & Yes & Yes & Yes \\
\hline $\mathrm{N}$ & 6263 & 6238 & 6711 & 6278 & 6238 \\
\hline$R^{2}$ & 0.647 & 0.652 & 0.625 & 0.634 & 0.662 \\
\hline
\end{tabular}

Notes: $\mathrm{p}$-values in brackets are based on the Huber-White standard errors. ***, ** and * denote significance at the $1 \%, 5 \%$ and $10 \%$ levels respectively. The R-squared is the adjusted R-squared. Constant value is not shown for brevity. OD, ForeignOwn, and Exports are mean-centred. OD $\times$ ForeignOwn and $\mathrm{OD} \times$ Exports refer to the interaction between mean-centred outside directors and mean-centred foreign ownership and between mean-centred outside directors and mean-centred exports respectively. Refer to Table 4 for definitions of other variables. 
FIGURE 2_A: Interaction effects between governance and foreign ownership on productivity

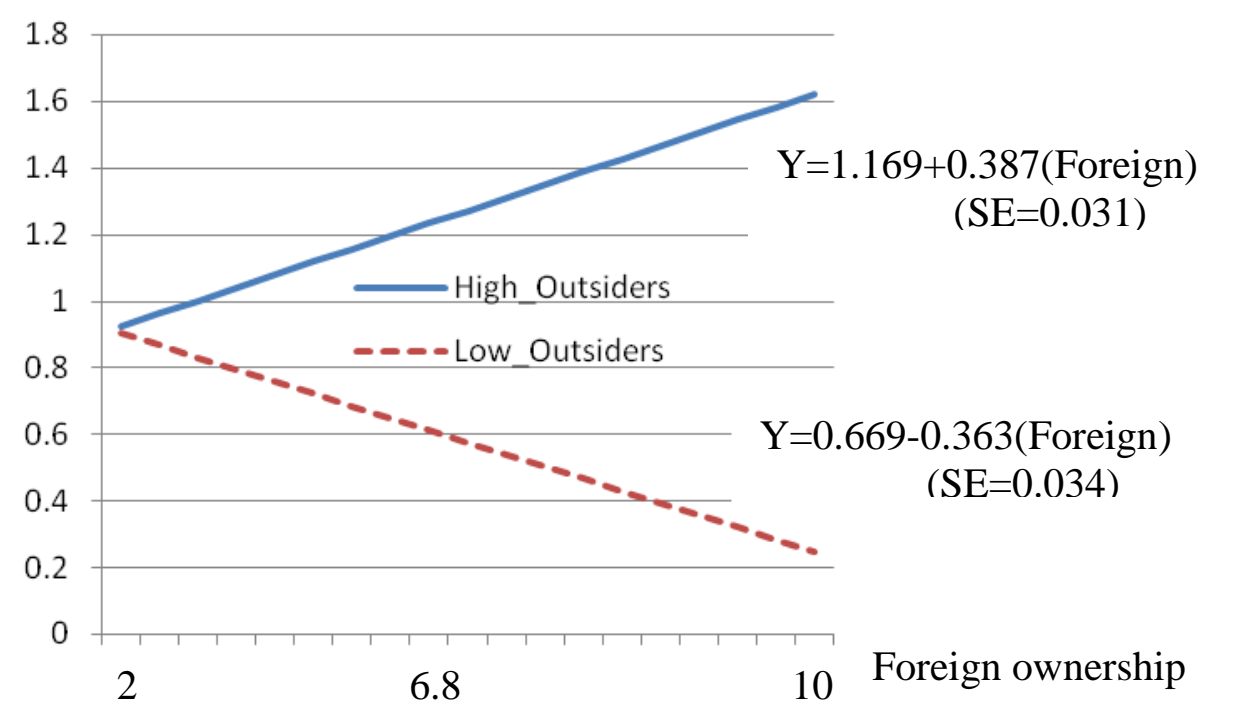

Note: High_Outsiders and Low_Outsiders refer respectively to the value of high and low quartile of the distribution of outside directors scaled by board members. Foreign denotes mean-centered foreign equity ownership. SE refers to standard error. SE is calculated by

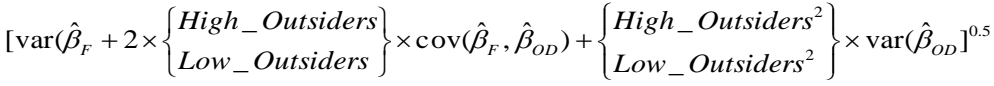

where $\hat{\beta}_{F}$ and $\hat{\beta}_{O D}$ refers to estimated coefficients of Foreign and outside director variable respectively. Average of mean-centred foreign ownership is 6.8 percent.

FIGURE 2_B: Interaction effects between governance and export on productivity

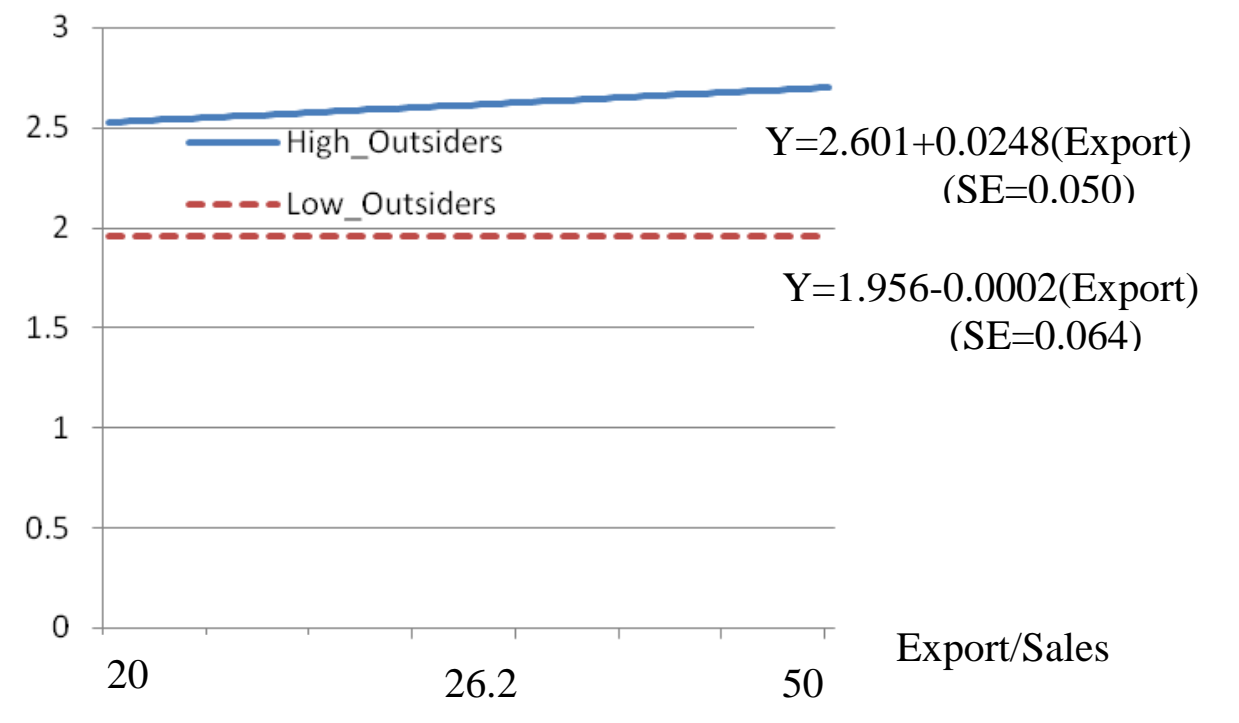

Note: High_Outsiders and Low_Outsiders refer respectively to the value of high and low quartile of the distribution of outside directors scaled by board members. Export denotes mean-centered Export/Sales. SE refers to standard error. SE is calculated by $\left[\operatorname{var}\left(\hat{\beta}_{E}+2 \times\left\{\begin{array}{l}\text { High_Outsiders } \\ \text { Low_Outsiders }\end{array}\right\} \times \operatorname{cov}\left(\hat{\beta}_{E}, \hat{\beta}_{O D}\right)+\left\{\begin{array}{l}\text { High_Outsiders }^{2} \\ \text { Low_Outsiders }^{2}\end{array}\right\} \times \operatorname{var}\left(\hat{\beta}_{O D}\right]^{0.5}\right.\right.$

where $\hat{\beta}_{E}$ and $\hat{\beta}_{O D}$ refers to estimated coefficients of exports and outside director variable respectively. Average value of mean-centred Export/Sales is 26.2 percent. 
TABLE 6: Results for chaebol affiliates and independent firms

\begin{tabular}{|c|c|c|c|c|c|}
\hline & $(1)$ & $(2)$ & (3) & (4) & (5) \\
\hline \multirow[t]{2}{*}{ Outside Director $(O D)$} & $0.039 * * *$ & $0.038 * * *$ & $0.003 * * *$ & $-0.029 * * *$ & $-0.042 * * *$ \\
\hline & {$[0.000]$} & {$[0.000]$} & {$[0.004]$} & {$[0.000]$} & {$[0.000]$} \\
\hline \multirow[t]{2}{*}{ Chaebol } & $-1.830 * * *$ & $-1.408 * * *$ & $-0.892 * * *$ & $-0.878 * * *$ & $-2.057 * * *$ \\
\hline & {$[0.000]$} & [0.000] & {$[0.000]$} & {$[0.000]$} & [0.000] \\
\hline \multirow[t]{2}{*}{ ChaebolXOD } & & 0.003 & $-0.017^{*}$ & $-0.017^{*}$ & $0.034 * * *$ \\
\hline & & {$[0.712]$} & {$[0.065]$} & {$[0.061]$} & {$[0.001]$} \\
\hline \multirow[t]{2}{*}{ OD $\times$ ForeignOwn } & & & $0.003 * * *$ & $0.003 * * *$ & $0.004^{* * *}$ \\
\hline & & & {$[0.000]$} & {$[0.000]$} & {$[0.000]$} \\
\hline \multirow[t]{2}{*}{ Foreign Ownership } & & & -0.011 & -0.002 & -0.001 \\
\hline & & & {$[0.275]$} & {$[0.801]$} & {$[0.893]$} \\
\hline \multirow[t]{2}{*}{$O D \times$ Exports } & & & & $0.001 * * *$ & $0.001^{* * *}$ \\
\hline & & & & {$[0.000]$} & {$[0.000]$} \\
\hline \multirow[t]{2}{*}{ Exports } & & & & $0.003^{*}$ & 0.001 \\
\hline & & & & {$[0.086]$} & [0.593] \\
\hline \multirow[t]{2}{*}{ OD $\times_{\text {Foreign }} \times$ Chaebol } & & & & & $-0.002 * * *$ \\
\hline & & & & & {$[0.005]$} \\
\hline \multirow[t]{2}{*}{ OD ${ }^{\text {Exports }} \times{ }$ Chaebol } & & & & & $-0.001 * *$ \\
\hline & & & & & {$[0.022]$} \\
\hline \multirow[t]{2}{*}{$H H I$} & & & & & $0.020 * * *$ \\
\hline & & & & & {$[0.000]$} \\
\hline \multirow[t]{2}{*}{$R \& D$} & & & & & $0.459 * * *$ \\
\hline & & & & & {$[0.002]$} \\
\hline \multirow[t]{2}{*}{ Firm Age } & & & & & $0.032^{*}$ \\
\hline & & & & & {$[0.073]$} \\
\hline \multirow[t]{2}{*}{ Firm Age2 } & & & & & $-0.001 * *$ \\
\hline & & & & & {$[0.013]$} \\
\hline \multirow[t]{2}{*}{ Regulation } & & & & & $-0.234 * * *$ \\
\hline & & & & & {$[0.008]$} \\
\hline \multirow[t]{2}{*}{ Training } & & & & & 0.005 \\
\hline & & & & & {$[0.207]$} \\
\hline \multirow[t]{2}{*}{ Skilled Labor } & & & & & $0.901^{*}$ \\
\hline & & & & & [0.080] \\
\hline \multirow[t]{2}{*}{ Patent Cost } & & & & & $-0.625 * * *$ \\
\hline & & & & & {$[0.004]$} \\
\hline Firm fixed effects & Yes & Yes & Yes & Yes & Yes \\
\hline Year fixed effects & Yes & Yes & Yes & Yes & Yes \\
\hline $\mathrm{N}$ & 6755 & 6755 & 6263 & 6263 & 6238 \\
\hline$R^{2}$ & 0.607 & 0.607 & 0.647 & 0.658 & 0.668 \\
\hline
\end{tabular}

Notes: p-values in brackets are based on the Huber-White standard errors. ***,** and * denote significance at the $1 \%, 5 \%$ and $10 \%$ levels respectively. The R-squared is the adjusted R-squared. Constant value is not shown for brevity. Chaebol is a binary variable equal to 1 if a firm belong to a business group and 0 otherwise. OD, ForeignOwn, and Exports are mean-centred. OD $\times$ ForeignOwn and OD $\times$ Exports refer to the interaction between outside directors(OD) and foreign ownership(ForeignOwn) and between outside directors and exports(Exports) respectively. $O D \times_{\text {Foreign }} \times{ }_{\text {Chaebol }}$ refers to the interaction between outside directors(OD), foreign ownership(ForeignOwn) and chaebol variables respectively. $O D \times{ }_{\text {Exports }} \times{ }_{\text {Chaebol }}$ refers to interaction between outside directors(OD), export/sales(Exports) and chaebol variables. Refer to Table 4 for definitions of other variables. 
TABLE 7: Instrumental variable estimation for baseline model

\begin{tabular}{|c|c|c|c|c|c|c|}
\hline & $(1)$ & $(2)$ & (3) & (4) & (5) & $(6)$ \\
\hline \multicolumn{7}{|l|}{ Outside } \\
\hline \multirow[t]{2}{*}{ Director(OD) } & $0.832 * * *$ & $0.809 * * *$ & $0.802 * * *$ & $0.857 * * *$ & $0.858 * * *$ & $0.828 * * *$ \\
\hline & {$[0.000]$} & {$[0.000]$} & {$[0.000]$} & {$[0.000]$} & {$[0.000]$} & {$[0.000]$} \\
\hline \multirow[t]{2}{*}{ Foreign Ownership } & & $0.025^{*}$ & $0.027 *$ & & & $0.028 * *$ \\
\hline & & [0.095] & {$[0.066]$} & & & {$[0.050]$} \\
\hline \multirow[t]{2}{*}{ Exports } & & & & $0.017 * * *$ & $0.016 * * *$ & $0.015 * * *$ \\
\hline & & & & {$[0.001]$} & {$[0.004]$} & {$[0.006]$} \\
\hline \multirow[t]{2}{*}{$H H I$} & & & $0.030 * * *$ & & $0.027 * * *$ & $0.028 * * *$ \\
\hline & & & {$[0.001]$} & & {$[0.003]$} & {$[0.002]$} \\
\hline \multirow[t]{2}{*}{$R \& D$} & & & 0.197 & & 0.111 & 0.153 \\
\hline & & & {$[0.506]$} & & {$[0.722]$} & {$[0.614]$} \\
\hline \multirow[t]{2}{*}{ Firm Age } & & & $0.059^{*}$ & & 0.040 & 0.050 \\
\hline & & & {$[0.081]$} & & {$[0.275]$} & {$[0.151]$} \\
\hline \multirow[t]{2}{*}{ Firm Age2 } & & & -0.001 & & -0.001 & -0.001 \\
\hline & & & {$[0.177]$} & & {$[0.386]$} & {$[0.233]$} \\
\hline \multirow[t]{2}{*}{ Regulation } & & & -0.404 & & -0.460 & -0.438 \\
\hline & & & {$[0.160]$} & & {$[0.136]$} & {$[0.140]$} \\
\hline \multirow[t]{2}{*}{ Training } & & & $0.049 * * *$ & & $0.052 * * *$ & $0.054 * * *$ \\
\hline & & & {$[0.000]$} & & {$[0.000]$} & {$[0.000]$} \\
\hline \multirow[t]{2}{*}{ Skilled Labor } & & & 0.291 & & 0.343 & 0.067 \\
\hline & & & {$[0.815]$} & & [0.794] & {$[0.958]$} \\
\hline \multirow[t]{2}{*}{ Patent Cost } & & & 0.171 & & 0.144 & 0.161 \\
\hline & & & {$[0.880]$} & & [0.906] & [0.893] \\
\hline$R^{2}$ & 0.595 & 0.587 & 0.591 & 0.597 & 0.590 & 0.593 \\
\hline $\mathrm{N}$ & 6309 & 5919 & 5909 & 6278 & 5943 & 5909 \\
\hline Rmse & 9.95 & 9.94 & 9.84 & 10.21 & 10.43 & 10.09 \\
\hline Year effects & Yes & Yes & Yes & Yes & Yes & Yes \\
\hline \multicolumn{7}{|l|}{$\begin{array}{l}\text { First Stage } \\
\text { excluded } \\
\text { instruments }\end{array}$} \\
\hline \multirow[t]{2}{*}{ Board_L } & $0.558 * * *$ & $0.497 * * *$ & $0.500 * * *$ & $0.549 * * *$ & $0.511 * * *$ & $0.491 * * *$ \\
\hline & {$[0.001]$} & [0.003] & {$[0.003]$} & {$[0.002]$} & {$[0.003]$} & {$[0.004]$} \\
\hline \multirow[t]{2}{*}{ Ln(asset)_L } & $1.356 * * *$ & $1.308 * * *$ & $1.350 * * *$ & $1.254 * * *$ & $1.361 * * *$ & $1.249 * *$ \\
\hline & {$[0.000]$} & {$[0.000]$} & {$[0.000]$} & {$[0.000]$} & {$[0.000]$} & {$[0.010]$} \\
\hline F-value(P-value) & $580.6(0.00)$ & $559.1(0.00)$ & $407.9(0.00)$ & $556.5(0.00)$ & $405.4(0.00)$ & $394.3(0.00)$ \\
\hline
\end{tabular}

Notes: GMM is used for the estimation. p-values in brackets are based on the Huber-White estimation method.***, $* *$ and $*$ denote significance at the $1 \%, 5 \%$ and $10 \%$ levels respectively. The R-squared is the adjusted R-squared. Board_L and Ln(asset)_L are lagged board size and natural logarithm of assets respectively. rmse refers to the root mean squared value. 